\title{
Aluminum: Bauxite-Alumina-Carbon Reduction
}

\author{
ALTON TABEREAUX ${ }^{1,2}$ \\ 1.-Muscle Shoals, AL 35661, USA. 2.-e-mail: attaber@aol.com
}

The aluminum section of the February issue of $J O M$ has a unique combination of articles regarding past and future electrolytic technologies in HallHéroult cells. In the article, "Cathode Characterization With Steel and Copper Inserts in Collector Bars in an Electrolytic Cell" by Subrat Das, Yos Morsi, and Geoffrey Brooks, one-quarter cell threedimensional (3-D) finite-element-method model simulation results are presented for one of the newest innovations-cathode copper inserts in collector bars in industrial cells that demonstrate the potential for lower cathode voltage drop, improvement in current distribution, and a decrease in Lorentz forces.

A historical perspective is presented in "Very High Purity Aluminum: An Historical Perspective" by Stephen J. Lindsay for the production of highpurity aluminum metal grades that approach the practical limits of purity from conventional aluminum electrolytic cells. Many of the work methods, systems, and subprocesses that have enabled the production of "very high purity" ingot in aluminum reduction cells since the early twentieth century are now obsolete for the designs of new smelters. Yet, a few primary aluminum smelters can, and do, produce limited quantities of super purity metal that is between $99.95 \%$ and $99.97+\% \mathrm{Al}$.

The last paper in this section is "The Evolution of Søderberg Aluminum Cell Technology in North and South America" by Mike Barber and Alton T. Tabereaux. The evolution of Søderberg technology in North and South America is illustrated beginning with the proliferation of Søderberg aluminum smelters during the 1940s and continued into the 1970 s due to the increased demand for aluminum metal. In the 1970s, 24 Søderberg smelters located in North and South America had a primary aluminum capacity greater than 3 million tpy. At the outset, the less expensive Søderberg cell technology provided a distinct advantage compared with the small Hall-Héroult prebake cell smelters at that time due to its lower costs and ability to increase the initial low amperage in the 1950s-1960s. However the higher-amperage modern prebake cells developed in the 1970s operated more efficiently with higher productivity. Eventually, Søderberg cells proved to be more difficult to automate and had significant environmental and health issues. 